\title{
Glanzmann Trombastenili Gebenin Peripartum Dönemde Yönetimi: Olgu Sunumu
}

\author{
Peripartum Management of a Pregnant with Glanzmann's \\ Thrombasthenia: A Case Report
}

\author{
Seda Ateş, Taner Molla, Fulya Özkal, Güven Çetin* , Gökçen Başaranoğlu** , Banu Dane \\ Bezmialem Vakıf Üniversitesi Tıp Fakültesi Hastanesi, Kadın Hastalıkları ve Doğum Anabilim Dalı, İstanbul, Türkiye \\ *Bezmialem Vakıf Üniversitesi Tıp Fakültesi Hastanesi, lç Hastalıkları Anabilim Dalı, Hematoloji Bilim Dalı, Istanbul, Türkiye \\ **Bezmialem Vakıf Üniversitesi Tıp Fakültesi Hastanesi, Anesteziyoloji ve Reanimasyon Anabilim Dalı, Istanbul, Türkiye
}

\section{Özet}

Kalıtsal trombosit fonksiyon bozukluğu olan Glanzmann trombastenisi (GT) tanısıyla takip edilen gebenin peripartum dönemde yönetiminin sağlanması. Yirmi altı yaşında GT tanısı olan gebenin takiplerinde doğumunun ilerlememesi ve aferez trombosit verilmesine rağmen vaginal kanamasının devam etmesi üzerine hastaya sezaryen doğum yaptırıldı ve doğum sonrası takibi gerçekleştirildi. Hastaya peripartum dönemde 18 ünite random trombosit, altı ünite aferez trombosit ve iki ünite eritrosit süspansiyonu verildi. GT olan hastaların özellikle doğum sırasında ve sonrasında ciddi kanama açısından yüksek risk altında olmaları nedeniyle doğumlarını deneyimli hematoloji uzmanlarının da bulunduğu ileri merkezlerde ve yakın takip altında yapmaları gerekmektedir. (Haseki Tıp Bülteni 2014; 52: 208-11)

Anahtar Sözcükler: Glanzmann trombasteni, gebelik, trombosit transfüzyon, doğum

\section{Abstract}

In this study, we aimed to present the case of a patient with Glanzmann's thrombasthenia (GT) which is a hereditary disorder characterized by defective platelet function. A twenty-six-year old woman with GT who underwent cesarean section due to labor arrest and persisting vaginal bleeding despite receiving 18 unit of random platelet concentrates, 6 units of apheresis platelet concentrates, and 2 units of erythrocyte suspension. Since patients with GT are at high risk for massive bleeding during and after delivery, they should give birth under close monitoring in advanced healthcare centers where experienced hematologists are available.

(The Medical Bulletin of Haseki 2014; 52: 208-11)

Key Words: Glanzmann's thrombasthenia, pregnancy, platelet transfusion, delivery

\section{Giriş}

Trombasteni trombositlerin sayısının sayıca normal olmasına karşın, fonksiyonlarında bozuklukluk olmasıdır. Bu hastalıklar konjenital ve edinsel olmak üzere iki grupta toplanır. Konjenital trombosit hastalıkları: Adezyon bozuklukları (Bernard-Solier sendromu), agregasyon bozuklukları (Glanzman hastalığı), release, sekresyon bozuklukları. Edinsel trombosit fonksiyon bozuklukları: Sistemik hastalıklar ve ilaçlara bağlı olabilir $(1,2)$.

Glanzmann thrombastenisi (GT) nadir görülen kalıtsal trombosit fonksiyon bozukluğu olup otozomal resesif geçiş 
gösterir (3). Akraba evliliklerinin fazla olduğu toplumlarda daha sık saptanmaktadır. Trombosit yüzeyinde fibronojenin bağlanması için ana reseptör olan trombosit glikoprotein (GP) 2a-3b'nin yapısal veya fonksiyonel bozukluğuna bağlı olarak trombosit agregasyonunun ve fibrin pıhtısının oluşmaması primer hemostazda ciddi sorunlara yol açar (4). Bu hastalarda platelet sayısı ve morfolojisi normal, kanama zamanı uzun ve trombosit agregasyonu eksik veya yoktur, pıhtı retraksiyonu yetersizdir (5). Periferik yaymada trombositler küme yapmaz tek tek görülür (6). Glikoprotein IIb-Illa düzeylerine göre hastalık üç alt tipe ayrlır, Tip 1: Glikoprotein düzeyi normalin $\% 5$ 'inden az olan olgular; Tip 2: \%5-\%20 arasında olan olgular; Tip 3: GP düzeyleri normal/normale yakın olmakla beraber işlevlerinde bozukluk vardır (5-7). Birçok hasta $(>2 / 3)$ hayatlarında en az bir kez kan veya trombosit transfüzyonuna intiyaç duyar (8). Hastalar genellikle beş yaşın altında pupura, peteşi, burun kanaması, dişeti kanaması veya travma sonrası durmayan kanamayla başvurur. Sindirim sistemi kanaması ve hematüri daha az görülür. Kadınlarda menarştan itibaren menoraji sık görülür ve genellikle transfüzyon intiyacı gerektirir (5). Trombastopeni'nin spesifik bir tedavisi yoktur. Herhangi bir cerrahi müdahele yapmadan önce trombosit süspansiyonu verilmelidir. Kanamanın tedavisinde topikal trombin, fibrin yapıştırıcı ve antifibrinolitik ilaçlar (aminokaproik asit ,traneksamik asit) kullanılır. GT'de saptanan kanama atak tedavisinde rFactor $7 a$ verilmesinin etkili bir tedavi olduğu gösterilmiştir $(6,9)$. Faktör 7 a subendotelyal fibrin üretimini arttırarak etkisini göstermektedir $(5,6,10)$. Ancak GT olan hastalarda Faktör 7 kullanımı ile tromboz gelişimi literatürde bildirilmiştir $(6,11)$. Ancak Rekombinan F7a kullanımı pahalı bir tedavi olduğu unutulmamalıdır (6). GT hastalarda gebelik önemli bir sorun olup hem anne hem fetüs kanama açısından artmış risk altındadır. Kanama paterni oldukça değişken olup olarak bazı hastalarda sadece mukokütanöz kanamalar gözlenirken bazılarında hayatı tehdit edecek kadar ciddi kanama görülebilir (3). Kliniğimizde takip ettiğimiz GT'li gebenin ve literatürdeki diğer GT tanısıyla doğum yapan gebelerin yönetimini anlatmayı amaçladık.

\section{Olgu}

Yirmi altı yaşında primigravid gebe GT Tip 2 tanısıyla kadın hastalıkları ve doğum kliniğimizde 15 haftalık gebelikten itibaren takip edilmeye başlandı. İlk kez iki yaşında düşme sonrası kontrol edilemeyen burun kanaması nedeniyle hospitalize edildikten ve kan transfüzyonu uygulandıktan sonra, yapılan ileri tetkikler sonrası GT Tip 2 tanısı konulmuştur. Menarş sırasında ve adolesan çağda uzamış adet kanamaları nedeniyle dönem dönem hastaneye yatırılarak kan transfüzyonu uygulanmıştır. 2007 yılında düşmeye bağlı olarak dizinde hematom oluşan hastaya trombosit transfüzyonı yapılmıştır. Hastaya 2012 yılında akut batın ve hemorajik kist rüptürü nedeniyle laparotomi uygulanmış ve ameliyat öncesinde ve sonrasında herhangi bir sorunla karşılaşılmamıştır. İki yıllık evli olan hasta erkek infertilitesi nedeniyle in vitro fertilizasyon (IVF) yöntemiyle gebe kalmıştır. Kliniğimizde hastaya hematoloji uzmanı ile birlikte konsülte edilerek gebeliği boyunca yakın antenatal takip yapıldı. Gebelik takibi boyunca trombosit sayısı normal olarak izlendi. Gebenin ilk trimesterden itibaren tekrarlayan ve kendiliğinden duran diş eti kanaması dışında kanama öyküsü olmamıştır. Gebelik haftası 39 hafta dört gün olan gebe, rutin gebelik takibi için polikliniğimize başvurduğu sırada yapılan vajinal muayenede serviks açıklığı üç $\mathrm{cm}$ silinmesi \%50 tespit edilip, non-stress test (NST)'de düzenli kontraksiyonlarının saptanması üzerine hasta doğum amacıyla yatııılı. Vajinal muayenesi sonrası sızıntı şeklinde başlayan kanaması olan hastanın yapılan ultrasonografide plasentası posterior duvarda olup, plasentada dekole alan saptanmadı. Hastaya doğum öncesi profilaksi amacıyla trombosit transüzyonu yapılması kararlaştıııldı.On sekiz ünite random trombosit (6-8 ünite random 1 aferez) ve traneksamik asit $250 \mathrm{mg}$ (transamine amp.) 2×16 verildi. Aferez trombosit hazırlanana kadar gebeye sürekli fetal monitarizasyon ve vajinal kanama takibi yapıldı. Hastanın takiplerinde doğumunun ilerlememesi ve üç ünite aferez trombosit verilmesine rağmen sızıntı şeklinde vaginal kanamasının devam etmesi üzerine hastaya sezaryen yapılmasına karar verildi. Laboratuvar tetkiklerinde hb: 10g/dl htc: 33,6 plt: 198.000/ml PT:13,1 saniye APTT:37,9 saniye INR: 0,98 takip sırasında hb: 7,5 g/dl htc: 25,2' ye düşmesi üzerine operasyondan bir saat önce iki ünite eritrosit süspansiyonu ve iki ünite aferez trombosit transfüzyonu yapılması kararlaştııldı. Hasta yatışından ortalama 24 saat sonra sezaryena alındı ve $3450 \mathrm{gr}$ ağılığında 6-9 APGAR'lı kız bebek doğurtuldu. Sezaryen sırasında alt segmentten başlayan yaklaşık dört $\mathrm{cm}^{\prime}$ lik koronal planda servikse uzanım gösteren lasere septum izlendi. Defekt repare edildi. Travay sırasındaki vaginal kanamanın alt segmente uzanan septuma bağlı olabileceği düşünüldü. Alt segmente tamponad amaçı Foley sonda balonu 50 cc şişirilerek uterin kaviteye yerleştirildi. Foley sondanın diğer ucu vajenden dışarı alındı. Opearsyon sırasında 10 ünite IV bolus ve 30 ünite/ saat infüzyon şeklinde oksitosin (synpitan amp.), Metilergobasin maleat $0,2 \mathrm{mg}$ (methergine amp.) verildi. Operasyon sonrası hastaya iki ünite eritrosit süspansiyonu verildi. Postoperatif birinci günde anormal bir vajinal kanama olmaması üzerine foley tamponad çıkarıldı. Takiplerinde loşi miktarı ve natürü doğal izlendi. Postoperatif üç gün boyunca hergün bir ünite aferez trombosit verildi. Postoperatif dönemde ilk 24 saat içinde batın içi drenden 200 cc cilt altı drenden 40 cc 


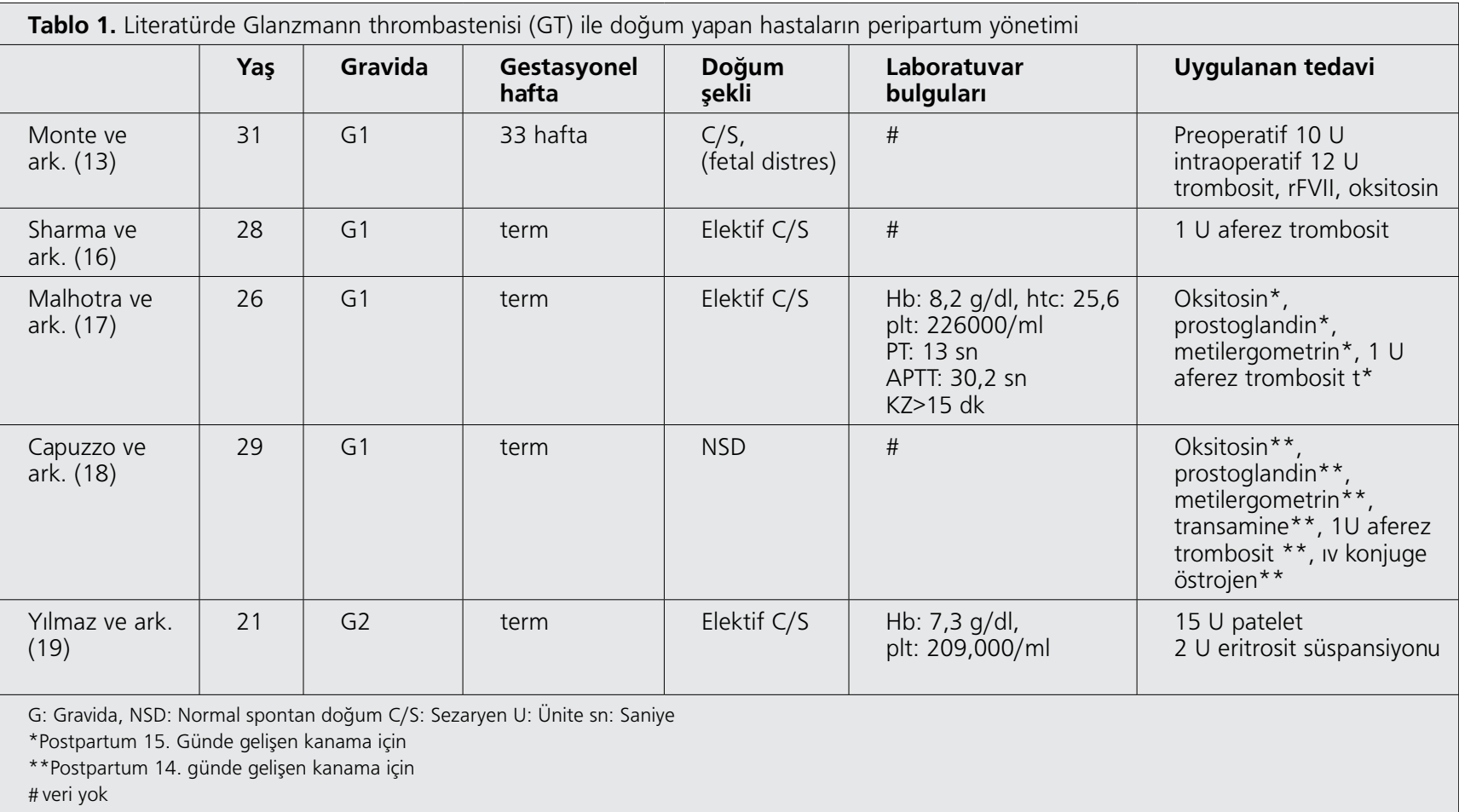

sero hemorajik mai gelmiş olup hasta postoperatif iki gün yoğun bakımda üç günde serviste takip edilerek sorunsuz bir şekilde taburcu edilmiştir. Yenidoğanın trombosit sayımı normal olup, yapılan kranial ultrasonografide kanama alanı izlenmedi. Hastada puerperal dönem boyunca herhangi bir kanama izlenmemiştir.

\section{Tartışma}

GT ile gebe kalan kadınlarda antenatal kanama oranı \%50 olarak bildirmiş olup tipik olarak mukokütanöz kanamalar, üriner sistemden kaynaklanan kanamalar gibi gebeliğe bağlı olmayan kanamalardır. Mukokütanöz kanamalar sağlıklı gebelerde de sık görülür ve GT'li gebe kadınlarda daha sık ve şiddetli değildir. Kontrol edilemeyen ciddi antenatal kanama riski düşük olup antenatal anormal vaginal kanama sadece iki vakada bildirilmiştir (12). Bizim vakamızda da hastanın ilk trimesterden itibaren tüm gebeliği boyunca devam eden ve kendiliğinden duran dişeti kanaması dışında herhangi bir kanama şikayeti olmamıştır. Hasta dişeti kanamasına yönelik herhangi bir tedaviye intiyaç duymamıştır.

$\mathrm{Bu}$ hastalarda invazif bir işlemden önce veya ciddi kanama sonrası trombosit transfüzyonu yapmak şarttır (5). Bu hastalarda doğum sırasında ve sonrasında oluşan kanamayı önlemek için trombosit transfüzyonu ana dayanak olup cerrahi sırasında iyi hemostaz yapmak ve oksitosin infüzyonuda kanama kontrolü açısından önemlidir (13). Trombosit transfüzyonu, GP 2a-3b'ye karşı izoantikor (anti trombosit antikorları) oluşma riskine neden olabilmektedir bu da bir sonraki transfüzyonun etkinliğini azaltmaktadır. Her ne kadar tek donörden hazırlanmış trombosit transfüzyonunun birçok donörden hazırlanarak elde edilmiş trombosit transfüzyonundan üstünlüğü kesin olarak kanıtlanmamış olsa da özellikle hayatı tehdit edebilen doğum sırasındaki kanamalarda tek donörden hazırlanmış olan trombositleri tercih etmek daha akıllıca görünmektedir. Maternal alloimmunizasyon gelişen kadınların tedavisinde plazmaferez, tek donörden veya HLA'sı uygun trombosit transfüzyonu, gammaglobülin veya rF7 infüzyonu önerilmiştir (13).

Maternal alloimmunizasyon fetal trombositopeni ile ilgili olup, GT'li gebelerden doğan yenidoğanlara trombosit sayımı ve intrakranial kanama riski açısından kranial ultrasonografi yapılmalıdır. Bu hastalarda postpartum kanama ortalama olarak doğumdan 10 gün sonra meydana gelebilmektedir. Bu nedenle bu hastaların doğumlarında herhangi bir sorun yaşanmasa ve gerekli profilaksi yapılsa bile doğum sonrası ilk 15 gün yakın takip altında tutulmalıdırlar. Postpartum kanamanın profilaksisinde rF7 a'nın uygulandığı sınırlı sayıda vaka bildirilmiş olup etkinliği değerlendirmek için ileri çalışmalara ihtiyaç vardır ancak maternal alloimmunizasyon riskini azaltma açısından oldukça güvenli görülmektedir (12). Hormonal tedavi olarak desmopressin kullanılmış olup herhangi klinik yararlanımı görülmemiştir (14).

GT'li hastalarda gebeliğin kendisi ciddi kanama riski ile ilgili görülmemektedir ancak doğum sırasında ve sonrasında 
ciddi kanama açısından yüksek risk altında olduklarından dolayı bu hastaların doğumlarını GT hastaların takibinde deneyimli hematologların da bulunduğu ileri merkezlerde yapmaları önerilmektedir (15).

GT'li hastalarda gebelikle ilgili morbidite ve mortalite insidansı bilinmemektedir ve

GT'li hastalarda gebe takibi ve yönetimi hakkında literatürde sınırlı sayıda bilgi bulunmaktadır. Literatürdeki GT'li gebelerin peripartum yönetimi Tablo 1'de sunulmuştur.

GT ile gebe kalan kadınların doğum sırası ve sonrasında oluşan obstetrik kanamaların tedavisi hakkında çeşitli tedavi şekilleri bildirildiği halde en uygun tedavinin ne olduğu konusunda fikir birliği yoktur. Bu konuyla ilgili yapılmış ileri çalışmalara ihtiyaç vardır.

\section{Kaynaklar}

1. Handin RI. Bleeding and thrombosis. In:Braunwald E, Fauci AS, Kasper DL, Hauser SL, Longo DL, Jameson JL. Harrison's Principles of internal medicine. 15th ed. Mcgrave-Hillco, New York; 2000. p. 339-45.

2. Pekcelen Y, Çapa İç Hastalıkları Cilt1, S.757, ist,2007.

3. Di Minno G, Coppola A, Di Minno MN, Poon MC. Glanzmann's thrombasthenia (defective platelet integrin alphallb-beta3): proposals for management between evidence and open issues. Thromb Haemost 2009;102:1157-64.

4. Di Minno G, Capitanio AM, Thiagarajan P, Martinez J, Murphy $S$. Exposure of fibrinogen receptors on fresh and stored platelets by ADP and epinephrine as single agents and as a pair. Blood 1983;61:1054-9.

5. Sebastiano C, Bromberg M, Breen K, Hurford MT. Glanzmann's thrombasthenia: report of a case and review of the literature. Int J Clin Exp Pathol 2010;25;443-7.

6. Kutlubay B, Özdemir GN, Tüysüz G, Apak H, Celkan T. Glanzmann trombastenisi: Cerrahpaşa Tıp Fakültesi deneyimi. Türk Ped Arş 2012;47:104-6.

7. Nurden $A T$, Fiore $M$, Nurden $P$, Pillois $X$. Glanzmann thrombasthenia: a review of ITGA2B and ITGB3 defects with emphasis on variants, phenotypic variability, and mouse models. Blood 2011;118:5996-6005.
8. Toogeh G, Sharifian R, Lak M, Safaee R, Artoni A, Peyvandi F. Presentation and pattern of symptoms in 382 patients with Glanzmann thrombasthenia in Iran. Am J Hematol 2004;77:198-9.

9. Poon MC, Zotz R, Di Minno G, Abrams ZS, Knudsen JB, Laurian Y. Glanzmann's thrombasthenia treatment: a prospective observational registry on the use of recombinant human activated factor VII and other hemostatic agents. Semin Hematol 2006;43(Suppl 1):33-6.

10. Lisman T, Moschatsis S, Adelmeijer J, Nieuwenhuis HK, De Groot PG. Recombinant factor VIla enhances deposition of platelets with congenital or acquired alpha IIb beta 3 deficiency to endothelial cell matrix and collagen under conditions of flow via tissue factor-independent thrombin generation. Blood 2003;101:1864-70.

11. Wertz D, Boveroux P, Péters $P$, Lenelle J, Franssen C. Surgical resection of a sphenoid wing meningioma in a patient with Glanzmann thrombasthenia. Acta Anaesthesiol Belg 2011;62:83-6.

12. Siddiq S, Clark A, Mumford A. A systematic review of the management and outcomes of pregnancy in Glanzmann thrombasthenia. Haemophilia 2011;17:858-69.

13. Monte S, Lyons G. Peripartum management of a patient with Glanzmann's thrombasthenia using Thrombelastograph. Br J Anaesth 2002;88:734-8.

14. Lethagen S, Nilsson IM. DDAVP-induced enhancement of platelet retention: its dependence on platelet-von Willebrand factor and the platelet receptor GP Ilb/IIla. Eur J Haematol 1992;49:7-13

15. Bolton-Maggs PH, Chalmers EA, Collins PW, et al. A review of inherited platelet disorders with guidelines for their management on behalf of the UKHCDO. $\mathrm{Br} J$ Haematol 2006;135:603-33.

16. Sharma P, Gogia S, Zafar MS, Saraf A, Bhargava M. Glanzmann thrombasthenia in pregnancy: the value of a probing bleeding history. Clin Appl Thromb Hemost 2012;18:110-2.

17. Malhotra N, Chanana C, Deka D. Pregnancy in a patient of Glanzmann's thrombasthenia. Indian J Med Sci 2006;60:111-3.

18. Capuzzo E, Polatti F, Zara C. Glanzmann's thrombasthenia and puerperium. Int J Gynaecol Obstet 1997;57:313-4.

19. Yılmaz E, Turhan U, Şimşek Y, Çelik Ö, karaer A, Minareci Y. Glanzmann trombastenisi tanısı alan term gebenin yönetimi: Olgu sunumu. Perinataloji dergisi 2011;19:137-9. 